\title{
Survival in pediatric patients with cancer during the COVID-19 pandemic: scoping systematic review
}

\author{
Elisa Dorantes-Acosta ${ }^{1}$, Diana Ávila-Montiel${ }^{2}$, Miguel Klünder-Klünder ${ }^{3}$, Luis Juárez-Villegas ${ }^{4}$, and \\ Horacio Márquez-González ${ }^{2 *}$ \\ ${ }^{1}$ Biobanco de Investigación en Células Leucémicas; ${ }^{2}$ Investigación Clínica; ${ }^{3}$ Subdirección de Investigación; ${ }^{4}$ Departamento de Onco-Hematología. \\ Hospital Infantil de México Federico Gómez, Mexico City, Mexico
}

\begin{abstract}
Background: Coronavirus disease (COVID)-19 has currently affected 8,015,502 million people worldwide with global mortality around 5\%. Information in pediatric cancer patients is still limited, but it is emerging day by day. The objective of this scoping review was to analyze the available data associated with COVID-19 infection and mortality in pediatric cancer patients and to provide useful information to plan and design strategies in this group. Methods: $A$ search was conducted, and eight articles were obtained for qualitative analysis; 110 patients were included, all from cross-sectional studies. At the time of publication, all the analyzed documents reported no deaths associated with COVID-19. Results: According to the information, COVID-19 infection appears to be less severe in the pediatric population in comparison with adults and does not appear to be a cause of mortality in patients with childhood cancer. Conclusions: Given the nature of preliminary reports and a short follow-up in cancer patients, it is necessary to have medium- and long-term follow-up studies to determine the effects of infection and modifications to the treatments of these patients.
\end{abstract}

Key words: Coronavirus disease-19. Cancer. Children. Systematic review. Mortality.

\section{Sobrevida en pacientes pediátricos con cáncer durante la pandemia de COVID-19: revisión sistemática exploratoria}

\section{Resumen}

Introducción: La enfermedad conocida como COVID-19 ha afectado ya a 8,015,502 millones de personas en el mundo, con una mortalidad global de aproximadamente el 5\%. La información en pacientes pediátricos con cáncer es aún limitada y está surgiendo día a día. El objetivo de esta revisión sistemática fue conocer los datos disponibles sobre la COVID-19 y la mortalidad en los pacientes pediátricos con cáncer, y aportar información útil para planear y diseñar estrategias en este grupo. Métodos: Se llevó a cabo una búsqueda y se seleccionaron ocho artículos para realizar un análisis cuantitativo; se incluyeron 110 pacientes, todos provenientes de estudios transversales. Al momento de las publicaciones, no se documentaron fallecimientos asociados a la COVID-19 en los documentos analizados. Resultados:

\section{Correspondence:}

*Horacio Márquez-González

E-mail: horaciohimfg@gmail.com

Available online: 14-09-2020

Date of reception: 20-06-2020 Date of acceptance: 25-06-2020 DOI: 10.24875/BMHIM.20000174
Bol Med Hosp Infant Mex. 2020;77(5):234-241

www.bmhim.com 1665-1146/C 2020 Hospital Infantil de México Federico Gómez. Published by Permanyer. This is an open access article under the CC BY-NC-ND license (http://creativecommons.org/licenses/by-nc-nd/4.0/). 
De acuerdo con la información de esta revisión sistemática, la COVID-19 parece ser menos grave que en los adultos y no parece ser causa de mortalidad en pacientes pediátricos con cáncer. Conclusiones: Dada la naturaleza de los reportes preliminares y el corto seguimiento en los pacientes con cáncer, es necesario contar con estudios de seguimiento a mediano y largo plazo para conocer los efectos de la infección y de las modificaciones del tratamiento en estos pacientes.

Palabras clave: COVID-19. Cáncer infantil. Revisión sistemática exploratoria. Mortalidad.

\section{Introduction}

On June 15, 2020, the severe acute respiratory syndrome coronavirus 2 (SARS-CoV-2) disease (coronavirus disease [COVID]-19), which emerged in China, has resulted in 8,015,502 infections and 436,319 deaths ${ }^{1}$. Although the exact number of affected children $<18$ years of age is not precise, a frequency of $1-5 \%$ of total infections has been estimated. Therefore, there may be approximately $80,000-350,000$ children infected by this virus.

People over 60 are especially susceptible to severe complications of the disease. Consequently, there are significantly fewer reports on pediatric populations in scientific journals. A systematic review that analyzed clinical presentation in different age groups showed that the frequency of hospitalizations, mechanical ventilation support requirements, and mortality is higher in minors ${ }^{2}$.

Newborns, infants, and preschoolers are unable to have self-isolation and self-care, which represent a public health problem in terms of controlling the spread of the virus. These age groups are particularly sensitive and complex, as some international hospitals have banned visits to comply with social distance and quarantine protocol, as the primary caregiver may become infected. In other centers where primary caregivers are allowed, there are logistical challenges of controlling infections and increasing resources of these hospitals serving children ${ }^{3}$.

Although it seems that children are less likely to develop severe complications, recent studies have identified that children $<5$ years of age can develop severe clinical manifestations, perhaps explained by the immaturity of their immune system. There are only a few reports in the literature on the impact of COVID19 on the pediatric population. Dong et al. described the epidemiology of the first pediatric series affected by the pandemic, consisting of 2143 suspected or confirmed cases in children in China, with an average age of 7 years ${ }^{4}$. Regarding symptoms, $4.4 \%$ were classified as asymptomatic, while most showed moderate to severe symptoms. Children $<1$ year of age presented the most severe clinical forms and accounted for the only death in the series. No association or comorbidity with childhood cancer is mentioned in this report ${ }^{4}$.

In the United States of America, a report on a case series examining the characteristics of 5700 New York City patients between March and April 2020, the average age was 63 years, ranging from 0 to 107 years at admission. There was male predominance (60.3\%), and the most common comorbidity was high blood pressure $(56.6 \%)$. In this study, cancer was present in only $6 \%$ of patients. Thirty-four patients under the age of 18 were identified in this study, of which no deaths occurred, or cancer coexistence was reported ${ }^{5}$.

Another US publication on pediatric intensive care units (ICUs) described the characteristics of 74 children who required critical care. The study covered from March 18 to April 6. It was estimated that 176,190 individuals were infected, from which $30 \%$ of the cases were children $<2$ years of age and $46 \%$ of children between 12 and 17 years of age. The US epidemiologists project that, if $25 \%$ of the US population is infected by the end of 2020 , there might be 50,000 children with severe COVID19 , and 5400 may need mechanical ventilation ${ }^{6}$.

The situation becomes particularly complicated when analyzing data on children with cancer and their management during the pandemic. Chen et al. described the first report of a child with cancer and COVID-19, a patient with high-risk acute lymphoblastic leukemia (ALL) who developed fever (F) and neutropenia (N) with cough in late January 2020. Initially, the patient was positive for influenza, but due to the persistence of the symptoms and epidemiological suspicion, the child was tested for COVID-19, giving a positive result. This patient was treated with umifenovir, ribavirin, and recombinant gamma-1b interferon, but the clinical outcome is unknown?

Balduzzi et al. published the experience of a pediatric hemato-oncology and transplant center in Italy, where five cancer patients were reported positive for COVID19: three were managed at home, two required hospitalization, and all of these patients showed moderate symptoms and survived ${ }^{8}$. 
The speed at which contagion spreads and the increased demand on health systems has forced large cooperative centers at the international level to identify people in vulnerable conditions, who could be harmed if infected with COVID-19. These organizations have drawn up useful expert management recommendations and are urgently calling for collaboration and sharing of expertise among centers that care for pediatric cancer patients ${ }^{9}$. In this context, the St. Jude group has created a virtual space for collaboration ${ }^{10}$.

To date, only a few publications have reported on clinical monitoring and outcomes of pediatric patients with COVID-19 and cancer, which is likely to change rapidly.

\section{Methods}

We conducted a systematic exploratory review of the literature from December 2019 to June 10, 2020, to compare survival in patients $<18$ years of age with cancer, with or with no SARS-CoV-2 infection. Since only a few reports were published in letters-to-editor sections in the first month, articles with the following characteristics were included: observational (included in opinion sections or letters to the editor), cross-sectional, or longitudinal studies. The used sources of information were MEDLINE, TRIP Database, International Clinical Trials Registry Platform (WHO), The Cochrane Library, Wiley, LILACS, and Google Scholar.

In addition, we searched directly (snowball method) in the following journals: Nature, New England Journal of Medicine, Science, JAMA, ELSEVIER, Oxford University Press, The Lancet, and medRxiv. MEDLINE searches were conducted using keywords and terms, without methodological filters by type of article (Table 1).

The reference lists of retrieved full-text articles were also searched to identify additional relevant studies. Furthermore, a search of classified gray literature was performed within the registers of the Hospital Infantil de México Federico Gómez ${ }^{11}$.

The search terms used were keywords or $\mathrm{MeSH}$ terms (for the pediatric stage: pediatrics, children, child, infancy, infant, scholar, and adolescent; for cancer disease: oncology, hemato-oncology, cancer, solid tumors, and hematologic cancer; for SARS-CoV-2 disease: SARS-COV-2, COVID-19, and coronavirus 19; and for death: mortality, survivance, and death).

The articles that included patients with cancer $<18$ years of age infected with SARS-CoV-2 and data on their survival were selected. Case reports or those in which the pediatric populations studied had only one subject with cancer or those that determined other families of coronaviruses were excluded.

In those publications where the outcomes were not indicated, the corresponding author was contacted. If data were clarified, the document was included.

The variables identified were defined as follows:

- SARS-CoV-2 infection: confirmation by polymerase chain reaction (PCR) test.

- Cancer: consideration when the article referred to this condition within the population context or when the population was classified according to the type of cancer.

- Survival: in cross-sectional studies, survival was considered when the outcome of patients up to the time of analysis was clarified. In those publications where mortality was not reported, the corresponding authors were contacted by e-mail to clarify the variables of interest.

For data collection and extraction, two reviewers assessed the inclusion eligibility of studies independently. Relevant studies were retrieved, and the necessary information on the characteristics of the selected studies (methodological aspects) was extracted: participants, type of intervention, outcome variable, and outcome data. In both phases (study selection and data extraction), the reviewers resolved disagreements by consensus; if disagreement persisted, a third reviewer was consulted.

Data obtained were integrated into evidence tables with validation by both reviewers. The following information was considered: country of origin, type of design, the purpose of the study, results of the study, phase of treatment the patient was undergoing when presenting COVID-19 infection, and the clinical outcome.

Studies with information on the management or mortality of pediatric patients ( $<18$ years) with cancer and SARS-CoV-2 were included. Articles with information only on adults were excluded from the study.

\section{Statistical analysis}

The results were qualitative synthetized. The frequencies of the clinical variables and the outcome were expressed in frequencies and percentages.

\section{Results}

Initially, 2685 articles were identified from scientific journal searches and eight from other sources, of which 55 manuscripts were duplicated. Then, 63 abstracts were reviewed to select those that met eligibility 
Table 1. MeSH terms used for MEDLINE search strategies

- (((I“neoplasms"[MeSH Terms] OR "neoplasms"[All Fields]) OR “oncology"[All Fields]) OR "oncology"[All Fields]) AND ((I("pediatrics"[All Fields] OR "pediatrics"[MeSH Terms]) OR "pediatrics"[All Fields]) OR "pediatric"[All Fields]) OR "pediatric"[All Fields])) AND (U((I(l“COVID-19"[All Fields] OR “COVID-2019"[All Fields]) OR "severe acute respiratory syndrome coronavirus 2"[Supplementary Concept]) OR "severe acute respiratory syndrome coronavirus 2"[All Fields]) OR "2019 nCoV"[All Fields]) OR "SARS-CoV-2"[All Fields]) OR "2019 nCoV"[All Fields]) OR (("Wuhan"[All Fields] AND ("coronavirus"[MeSH Terms] OR "coronavirus"[All Fields])) AND (2019/12/1:2019/12/31[Date - Publication] OR 2020/1/1:2020/12/31[Date - Publication])))

- I(I"severe acute respiratory syndrome coronavirus 2"[Supplementary Concept] OR "severe acute respiratory syndrome coronavirus 2"[All Fields]) OR "SARS-CoV-2"[All Fields]) AND (((I"pediatrics"[All Fields] OR "pediatrics"[MeSH Terms]) OR "pediatrics"[All Fields]) OR "pediatric"[All Fields]) OR "pediatric"[All Fields])) AND (U(U(U((“"cancers"[All Fields] OR "cancerated"[All Fields]) OR "canceration"[All Fields]) OR "cancerization"[All Fields]) OR "cancerized"[All Fields]) OR "cancerous"[All Fields]) OR "neoplasms"[MeSH Terms]) OR "neoplasms"[All Fields]) OR "cancer"[All Fields]) OR "cancers"[All Fields])) AND (((l"intensive care units"[MeSH Terms] OR ((“intensive"[All Fields] AND "care"[All Fields]) AND "units"[All Fields])) OR "intensive care units"[All Fields]) OR (("intensive"[All Fields] AND "care"[All Fields]) AND "unit"[All Fields])) OR “intensive care unit"[All Fields])

- (l“COVID"[All Fields] AND ((l("pediatrics"[All Fields] OR "pediatrics"[MeSH Terms]) OR "pediatrics"[All Fields]) OR "pediatric"[All Fields]) OR "pediatric"[All Fields])) AND ((I(U(U(1“cancers"[All Fields] OR "cancerated"[All Fields]) OR "canceration"[All Fields]) OR "cancerization"[All Fields]) OR "cancerized"[All Fields]) OR "cancerous"[All Fields]) OR "neoplasms"[MeSH Terms]) OR "neoplasms"[All Fields]) OR "cancer"[All Fields]) OR "cancers"[All Fields])) AND ((('“intensive care units"[MeSH Terms] OR (("intensive"[All Fields] AND "care"[All Fields]) AND "units"[All Fields])) OR "intensive care units"[All Fields]) OR (("intensive"[All Fields] AND "care"[All Fields]) AND "unit"[All Fields])) OR "intensive care unit"[All Fields])

- I( “"severe acute respiratory syndrome coronavirus 2"[Supplementary Concept] OR "severe acute respiratory syndrome coronavirus 2"[All Fields]) OR "SARS-CoV-2"[All Fields]) AND (I((I"child"[MeSH Terms] OR "child"[All Fields]) OR "children"[All Fields]) OR

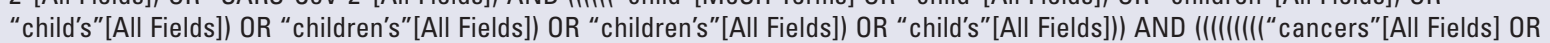
"cancerated"[All Fields]) OR "canceration"[All Fields]) OR "cancerization"[All Fields]) OR "cancerized"[All Fields]) OR "cancerous"[All Fields]) OR "neoplasms"[MeSH Terms]) OR "neoplasms"[All Fields]) OR “cancer"[All Fields]) OR "cancers"[All Fields])

- (((U“"pediatrics"[All Fields] OR "pediatrics"[MeSH Terms]) OR "pediatrics"[All Fields]) OR "pediatric"[All Fields]) OR "pediatric"[All Fields]) AND (I(I(I(“COVID-19"[All Fields] OR “COVID-2019"[All Fields]) OR "severe acute respiratory syndrome coronavirus 2"[Supplementary Concept]) OR "severe acute respiratory syndrome coronavirus 2"[All Fields]) OR "2019 nCoV"[All Fields]) OR "SARS-CoV-2"[All Fields]) OR "2019 nCoV"[All Fields]) OR (("Wuhan"[All Fields] AND ("coronavirus"[MeSH Terms] OR "coronavirus"[All Fields])) AND (2019/12/1:2019/12/31[Date - Publication] OR 2020/1/1:2020/12/31[Date - Publication]))) AND ((U(U(U("cancers"[All Fields] OR "cancerated"[All Fields]) OR "canceration"[All Fields]) OR "cancerization"[All Fields]) OR "cancerized"[All Fields]) OR "cancerous"[All Fields]) OR "neoplasms"[MeSH Terms]) OR "neoplasms"[All Fields]) OR "cancer"[All Fields]) OR "cancers"[All Fields])

- ((U(U("pediatrics"[All Fields] OR "pediatrics"[MeSH Terms]) OR "pediatrics"[All Fields]) OR "pediatric"[All Fields]) OR "pediatric"[All Fields]) AND (I(I(I“"COVID-19"[All Fields] OR “COVID-2019"[All Fields]) OR "severe acute respiratory syndrome coronavirus 2"[Supplementary Concept]) OR "severe acute respiratory syndrome coronavirus 2"[All Fields]) OR "2019 nCoV"[All Fields]) OR "SARS-CoV-2"[All Fields]) OR "2019 nCoV"[All Fields]) OR ((“Wuhan"[All Fields] AND ("coronavirus"[MeSH Terms] OR "coronavirus"[All Fields])) AND (2019/12/1:2019/12/31[Date - Publication] OR 2020/1/1:2020/12/31[Date - Publication])))) AND (("coronavirus"[MeSH Terms] OR “coronavirus"[All Fields]) OR “coronaviruses"[All Fields])) AND (((“mortality"[MeSH Terms] OR "mortality"[All Fields]) OR "mortalities"[All Fields]) OR "mortality"[MeSH Subheading])

- ("cancer"[All Fields] AND ("coronavirus"[All Fields] AND "19"[All Fields])) AND "pediatric"[All Fields]

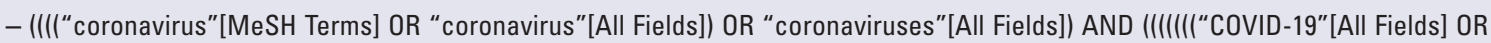
"COVID-2019"[All Fields]) OR "severe acute respiratory syndrome coronavirus 2"[Supplementary Concept]) OR "severe acute respiratory syndrome coronavirus 2"[All Fields]) OR "2019 nCoV"[All Fields]) OR "SARS-CoV-2"[All Fields]) OR "2019 nCoV"[All Fields]) OR (("Wuhan"[All Fields] AND ("coronavirus"[MeSH Terms] OR “coronavirus"[All Fields])) AND (2019/12/1:2019/12/31[Date Publication] OR 2020/1/1:2020/12/31[Date - Publication])))) AND (((("pediatrics"[All Fields] OR "pediatrics"[MeSH Terms]) OR "pediatrics"[All Fields]) OR "pediatric"[All Fields]) OR "pediatric"[All Fields])) AND ((("neoplasms"[MeSH Terms] OR "neoplasms"[All Fields]) OR “oncology"[All Fields]) OR “oncology"[All Fields]).

criteria; 27 were identified and were read completely (Fig. 1).

\section{Excluded articles}

Articles were excluded for the following criteria: seven articles which involved a single cancer patient (Gonzalez et al., 202012, Liguoro et al., 202013, Sun et al., $2020^{14}$, Wu et al., $2020^{15}$, Chao et al., $2020^{16}$, Sieni et al., $2020^{17}$, Lu et al., 202018) and four articles that included an adult population but no pediatric cases (Molica et al., 202019, Dai et al., 202020, Mehta et al., 202021, Zhang et al., 202022). In three articles (Dong et al., 20204, Lu et al., 202022, Yang et al., 202023), the reported population met the age criteria; however, since no selection criteria were 


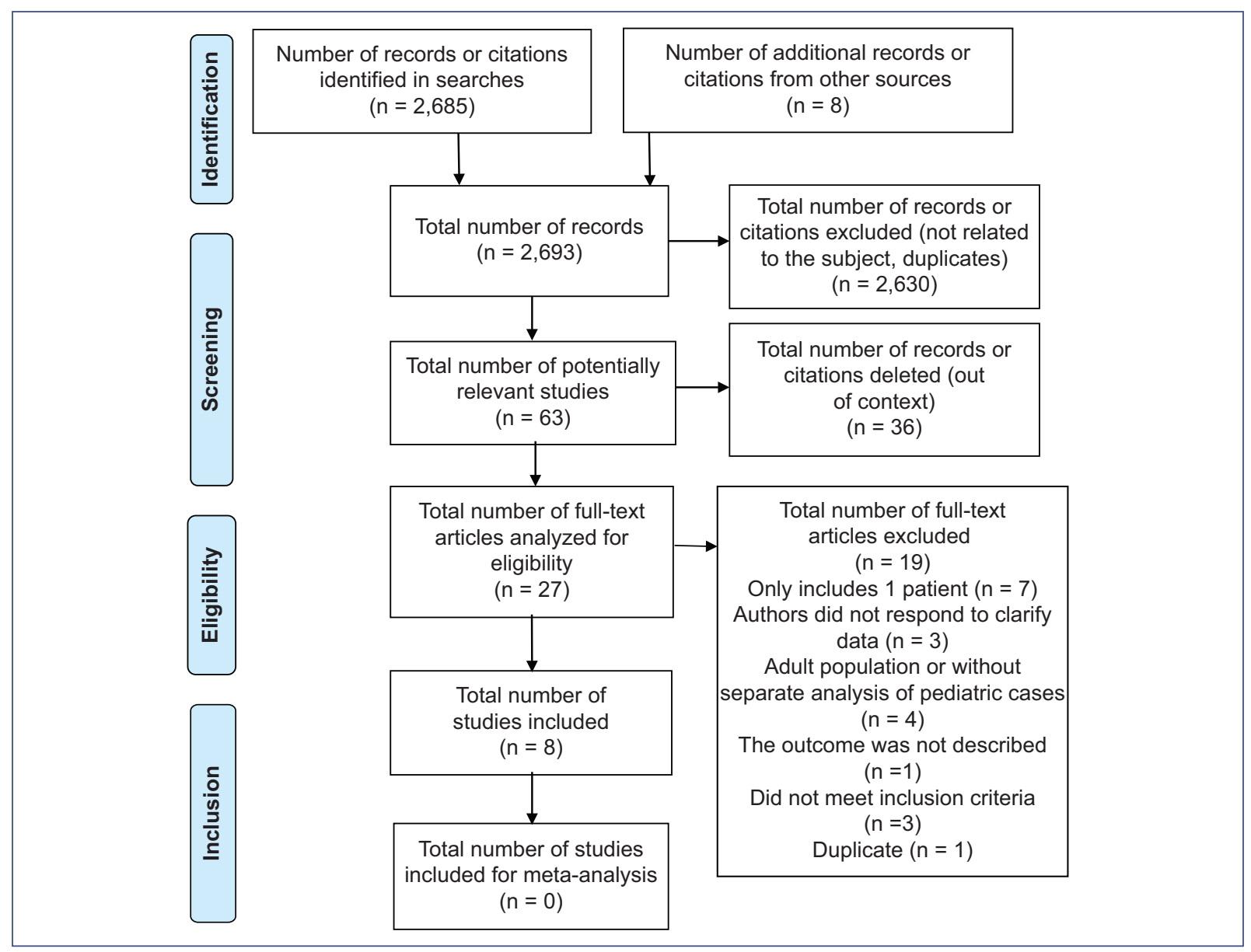

Figure 1. Flowchart of the systematic review according to the PRISMA guidelines.

available, it was not possible to identify whether any of these cases simultaneously presented cancer. In these cases, the corresponding authors were contacted; if there was no response, the articles were excluded. Furthermore, one report was discarded for not including an outcome (Terenziani, 202024), and three more did not meet the inclusion criteria (Baruchel, 202025; Sullivan, 202026; Shekerdemian, 201927); finally, one duplicated study was excluded as well (Ruggiero, 202028).

\section{Included articles}

Eight articles were included (Table 2): Andre et al., $2020^{29}$, Balduzzi et al., $2020^{8}$, Boulad et al., $2020^{30}$, de Rojas et al., $2020^{31}$, Ferrari et al., $2020^{32}$, Hrusak et al., $2020^{33}$, Zachariah et al., $2020^{34}$, and Garazzino et al., $2020^{35}$. A total of 110 patients were included in the analysis, all from cross-sectional studies.
Although some patients were seriously ill in an ICU, at the time of publication, no deaths associated with COVID-19 were documented.

In addition, 14 patients from the hospital census at the Hospital Infantil de México Federico Gómez were included; seven of them required hospitalization, but none was critically ill or required intensive care at the time of publication.

\section{Discussion}

Regarding the evidence on COVID-19, scientific journals have given priority for disseminating the published information so that these manuscripts reach a higher number of readers. However, in some cases, the reports are preliminary, with heterogeneous populations, partial follow-ups, and scenarios that make it difficult to adjust for confounding variables.

In this systematic review, it was not possible to complete a meta-analysis because most of the included 
Table 2. Description of studies of pediatric cancer patients infected with coronavirus disease (COVID-19)

\begin{tabular}{|c|c|c|c|c|c|c|}
\hline $\begin{array}{l}\text { Author, year } \\
\text { [reference] }\end{array}$ & Country & Design & Objective & Results & Stage of treatment & Outcome \\
\hline $\begin{array}{l}\text { André et al., } \\
2020^{* 29}\end{array}$ & France & $\begin{array}{l}\text { A multicentric } \\
\text { descriptive } \\
\text { cross-sectional } \\
\text { study }\end{array}$ & $\begin{array}{l}\text { Reporting the } \\
\text { diagnosis in pediatric } \\
\text { cancer patients and } \\
\text { their clinical } \\
\text { characteristics }\end{array}$ & $\begin{array}{l}\text { In } 19 \text { cancer centers, } 33 \text { cases } \\
\text { were confirmed by PCR, five of } \\
\text { which required hospitalization in } \\
\text { ICUs }\end{array}$ & $\begin{array}{l}\text { One of the patients } \\
\text { who required ICU } \\
\text { management } \\
\text { coincided the } \\
\text { episode with the } \\
\text { administration of } \\
\text { chemotherapy }\end{array}$ & $\begin{array}{l}100 \% \\
\text { survival }\end{array}$ \\
\hline $\begin{array}{l}\text { Balduzzi et al., } \\
2020^{8}\end{array}$ & Italy & $\begin{array}{l}\text { Descriptive } \\
\text { cross-sectional } \\
\text { study }\end{array}$ & $\begin{array}{l}\text { A review by experts } \\
\text { and the reporting of } \\
\text { positive cases from a } \\
\text { hospital facility }\end{array}$ & $\begin{array}{l}\text { PCR diagnosis of five cases: } \\
\text { ALL (1 case), osteosarcoma ( } 2 \\
\text { cases), hepatoblastoma ( } 2 \text { cases), } \\
\text { rhabdoid tumor ( } 1 \text { case). }\end{array}$ & - & $\begin{array}{l}100 \% \\
\text { survival }\end{array}$ \\
\hline $\begin{array}{l}\text { Boulad et al., } \\
2020^{* 30}\end{array}$ & $\begin{array}{l}\text { United } \\
\text { States }\end{array}$ & $\begin{array}{l}\text { Descriptive } \\
\text { cross-sectional } \\
\text { study }^{\ddagger}\end{array}$ & $\begin{array}{l}\text { A study that } \\
\text { evaluated the } \\
\text { diagnosis of COVID-19 } \\
\text { in children and } \\
\text { caregivers at a New } \\
\text { York hospital } \\
\text { attending population } \\
\text { with cancer }\end{array}$ & $\begin{array}{l}\text { Of } 335 \text { PCR tests performed on } \\
\text { patients and primary caregivers, } 20 \\
(11.5 \%) \text { were confirmed, five of } \\
\text { which showed moderate symptoms } \\
\text { that required hospitalization }\end{array}$ & $\begin{array}{l}\text { Three of the } \\
\text { hospitalized patients } \\
\text { presented fever and } \\
\text { neutropenia and } \\
\text { required } \\
\text { modifications to } \\
\text { their chemotherapy } \\
\text { treatment }\end{array}$ & $\begin{array}{l}100 \% \\
\text { survival }\end{array}$ \\
\hline $\begin{array}{l}\text { de Rojas et al., } \\
2020^{* 31}\end{array}$ & Spain & $\begin{array}{l}\text { Descriptive } \\
\text { cross-sectional } \\
\text { study }\end{array}$ & $\begin{array}{l}\text { To report the clinical } \\
\text { characteristics of } \\
\text { children with cancer } \\
\text { and COVID-19 in } \\
\text { Madrid }\end{array}$ & $\begin{array}{l}\text { In } 2 \text { months, } 1140 \text { PCR tests were } \\
\text { performed, of which } 1.3 \% \text { were } \\
\text { positive. There were } 15 \text { cases of } \\
\text { children, with a median age of } 10.6 \\
\text { years, presenting with the following } \\
\text { types of cancer: } 11(73 \%) \\
\text { hematological neoplasms, } 4(27 \%) \\
\text { solid tumors, and } 4 \text { with transplants }\end{array}$ & $\begin{array}{l}60 \% \text { presented the } \\
\text { infection during the } \\
\text { following } 15 \text { days } \\
\text { after chemotherapy }\end{array}$ & $\begin{array}{l}100 \% \\
\text { survival }\end{array}$ \\
\hline $\begin{array}{l}\text { Ferrari et al., } \\
2020^{* 32}\end{array}$ & Italy & $\begin{array}{l}\text { Multicentric } \\
\text { descriptive } \\
\text { cross-sectional } \\
\text { study }^{\ddagger}\end{array}$ & $\begin{array}{l}\text { Reporting the } \\
\text { characteristics of } \\
\text { Italian patients in the } \\
\text { region of Lombardy, } \\
\text { Italy }\end{array}$ & $\begin{array}{l}\text { Of } 4485 \text { PCR tests, } 286 \text { patients } \\
\text { were positive, identifying } 21 \text { cases } \\
\text { of COVID-19 with cancer (number } \\
\text { of cases): leukemia (10) sarcomas } \\
\text { (5), lymphomas (2), } \\
\text { hepatoblastomas (2), central } \\
\text { nervous system tumors (1), and } \\
\text { colon cancer (1) }\end{array}$ & $\begin{array}{l}15 \text { cases were } \\
\text { present during the } \\
1^{\text {st }} \text { day of } \\
\text { chemotherapy } \\
\text { courses; in } 10 \text { cases, } \\
\text { it was necessary to } \\
\text { adjust the } \\
\text { chemotherapy }\end{array}$ & $\begin{array}{l}100 \% \\
\text { survival }\end{array}$ \\
\hline $\begin{array}{l}\text { Hrusak et al., } \\
2020^{33}\end{array}$ & Italy & $\begin{array}{l}\text { Multicentric } \\
\text { descriptive } \\
\text { cross-sectional } \\
\text { study }^{\ddagger}\end{array}$ & $\begin{array}{l}\text { A brief report of the } \\
\text { participation of } 32 \\
\text { pediatric hospital } \\
\text { centers }\end{array}$ & $\begin{array}{l}\text { There were } 200 \text { cancer patients } \\
\text { tested with PCR, and eight positive } \\
\text { cases were reported. The types of } \\
\text { cancer (number of cases) were } \\
\text { ALL (2), hepatoblastoma (2), } \\
\text { osteosarcoma (1), rhabdoid tumor } \\
\text { (1), Ewing's sarcoma (1), Wilms' } \\
\text { tumor (1). } \\
\text { This study includes five patients } \\
\text { also reported by Balduzzi et al. }{ }^{8}\end{array}$ & $\begin{array}{l}\text { Seven of the cases } \\
\text { occurred during } \\
\text { chemotherapy and } \\
\text { were accompanied } \\
\text { by fever and } \\
\text { neutropenia }\end{array}$ & $\begin{array}{l}100 \% \\
\text { survival }\end{array}$ \\
\hline $\begin{array}{l}\text { Zachariah } \\
\text { et al., } 2020^{34}\end{array}$ & $\begin{array}{l}\text { United } \\
\text { States }\end{array}$ & $\begin{array}{l}\text { Comparative } \\
\text { cross-sectional } \\
\text { study }\end{array}$ & $\begin{array}{l}\text { To compare the } \\
\text { clinical } \\
\text { characteristics of } \\
\text { patients infected by } \\
\text { COVID-19 who } \\
\text { required and did not } \\
\text { require hospitalization } \\
\text { in intensive care }\end{array}$ & $\begin{array}{l}\text { Fifty cases were confirmed by } \\
\text { PCR, of which nine required } \\
\text { hospitalizations in ICU. The cases } \\
\text { with cancer were (number of } \\
\text { patients) solid organ tumors (2), } \\
\text { hematological neoplasms (2) }\end{array}$ & - & $\begin{array}{l}100 \% \\
\text { survival }\end{array}$ \\
\hline $\begin{array}{l}\text { Garazzino } \\
\text { et al., } 2020^{35}\end{array}$ & Italy & $\begin{array}{l}\text { Cross-sectional } \\
\text { study }\end{array}$ & $\begin{array}{l}\text { Preliminary report of } \\
\text { confirmed cases in } \\
\text { Italy }\end{array}$ & $\begin{array}{l}168 \text { confirmed cases were } \\
\text { obtained, of which } 110 \text { required } \\
\text { hospitalization, of which four had } \\
\text { cancer as a comorbidity }\end{array}$ & - & $\begin{array}{l}100 \% \\
\text { survival }\end{array}$ \\
\hline $\begin{array}{l}\text { HIMFG (report } \\
\text { up to June 13, } \\
\text { 2020) }\end{array}$ & Mexico & $\begin{array}{l}\text { Hospital Census } \\
\text { Report }\end{array}$ & $\begin{array}{l}\text { Patients of the } \\
\text { hematology and } \\
\text { oncology department }\end{array}$ & $\begin{array}{l}14 \text { cases were confirmed, of which } \\
\text { seven required hospitalization }\end{array}$ & - & $\begin{array}{l}100 \% \\
\text { survival }\end{array}$ \\
\hline
\end{tabular}

ALL: acute lymphoblastic leukemia; F: fever; N: neutropenia; HIMFG: Hospital Infantil de México Federico Gómez; ICU: intensive care unit; PCR: polymerase chain reaction. *Letter to the editor describing a population that met the selection criteria; łpatients from cancer hospitals; §data were retrieved from a national registry of children with cancer. 
articles were part of cross-sectional studies or early cohorts included in letters to the editor. For this reason, the case series obtained at the time the search was completed did not contain reports of deaths associated with COVID-19 infection. As expected, given the epidemiology of pediatric stage neoplasms, the highest number of cases occurred in patients with $\mathrm{ALL}^{36}$. Fever and neutropenia were frequently observed in most cases requiring hospitalization or ICU care. Furthermore, it should be considered that in non-pandemic scenarios, up to half of fever and neutropenia events require intensive care, and mortality from septic shock may increase up to $33 \%{ }^{37}$.

As shown in table 2, most of the publications included are reported by cancer centers that have the infrastructure and expertise to address these complications, including COVID-19 infection. The absence of deaths can be explained by the fact that experts in the field maintained the lead in medical care.

The strength of this exploratory review lies in the fact that the chronology of the pandemic is represented through the most affected countries, with a predominance of cases from Italy, Spain, France, and the United States. The low representation of China is noteworthy, probably due to a language bias ${ }^{38}$.

In this systematic review, the articles included for the analysis were those in which COVID-19 was confirmed by PCR and not by clinical criteria since this test is the gold standard. However, criteria for screening the pediatric population are not yet well defined.

As in any exploratory review, the following biases of the present review are mentioned:

a.Selection bias: selected publications included patients with various neoplasms and therapeutic phases.

b. Repeated information bias: some authors shared patients in their publications ${ }^{8,33}$.

c. Follow-up bias: the cross-sectional nature of the articles included does not allow to know whether these subjects could subsequently die in the following weeks or if they presented complications in the subsequent chemotherapies.

d. Reporting bias: the principal authors of the articles are experts in their fields, so there may be hospitals with related deaths that have not published their cases.

Regarding Mexico, it was not possible to identify information on these patients up to the time of the search. Therefore, reports from a concentration hospital in Mexico City, which is a reference center for the treatment of childhood cancer, are included as gray literature. The National Public Access Database provided by the Secretaría de Salud (Ministry of Health) reported 100 deaths in 6220 infected children, but it was not possible to identify any association with cancer, because the variable recorded was immunocompromise.

Regardless of some isolated efforts, there is a need to standardize diagnostic and management guidelines, for which the information in this systematic review may be useful.

Although data in the literature are limited, this systematic review shows that COVID-19 does not impact on infant mortality in the pediatric cancer population. Furthermore, the severe form of COVID-19 infection seems to occur less in children than in adults, which is consistent with the isolated opinions of other authors. It might be possible that the biology of the disease is different between both age groups and that distinct management guidelines will have to be developed shortly.

The medium- and long-term impact of interrupting chemotherapy as a result of COVID-19 is not clear. Therefore, studies are needed to follow up and analyze this situation. In addition, many questions remain to be answered. For example, how long chemotherapy should be postponed when the infection is detected, which will be the recovery parameters, and if it is correct to screen the population with cancer.

The information above exposes the need for collaboration not only between different hospitals but also between different disciplines. This effort should be directed at protocolizing management and conducting clinical trials for the treatment of the disease. Moreover, education to patients and families about the disease, the consequences of isolation, prevention, and diagnostic methods should be protocolized. These actions will undoubtedly impact the care of this sensitive group, pediatric cancer patients.

Given the nature of preliminary reports and a short follow-up in cancer patients, it is necessary to have medium- and long-term follow-up studies to determine the effects of infection and modifications to the treatments of these patients.

\section{Ethical disclosures}

Protection of human and animal subjects. The authors declare that no experiments were performed on humans or animals for this study.

Confidentiality of data. The authors declare that they have followed the protocols of their work center on the publication of patient data. 
Right to privacy and informed consent. The authors have obtained the written informed consent of the patients or subjects mentioned in the article. The corresponding author is in possession of this document.

\section{Conflicts of interest}

The authors declare that they have no conflicts of interest.

\section{Funding}

None.

\section{Acknowledgments}

We are thankful to the Dirección de Investigación (Research Department) for trusting the relevance of the topic.

\section{References}

1. Coronavirus Resource Center. Baltimore; 2020. Available from: https:// www.coronavirus.jhu.edu/map.html

2. Singhal T. A review of coronavirus disease-2019 (COVID-19). Indian J Pediatr. 2020;87:281-6.

3. Ludvigsson JF. Systematic review of COVID-19 in children shows milder cases and a better prognosis than adults. Acta Paediatr. 2020;109:1088-95.

4. Dong $Y$, Mo X, Hu Y, Qi X, Jiang F, Jiang Z, et al. Epidemiology of COVID-19 among children in China. Pediatrics. 2020;145:e20200702.

5. Richardson S, Hirsch JS, Narasimhan M, Crawford JM, McGinn T, Davidson $\mathrm{KW}$, et al. Presenting characteristics, comorbidities, and outcomes among 5700 patients hospitalized with COVID-19 in the New York City area. JAMA. 2020:323:2052-9.

6. Pathak EB, Salemi JL, Sobers N, Menard J, Hambleton IR. COVID-19 in children in the United States: intensive care admissions, estimated total infected, and projected numbers of severe pediatric cases in 2020. J Public Health Manag Pract. 2020;26:325-33.

7. Chen Z, Xiong H, Li JX, Li H, Tao F, Yang YT, et al. COVID-19 with post-chemotherapy agranulocytosis in childhood acute leukemia: a case report. Zhonghua Xue Ye Xue Za Zhi. 2020;41:341-3.

8. Balduzzi A, Brivio E, Rovelli A, Rizzari C, Gasperini S, Melzi ML, et al. Lessons after the early management of the COVID-19 outbreak in a pediatric transplant and hemato-oncology center embedded within a $\mathrm{CO}$ VID-19 dedicated hospital in Lombardia, Italy. Estote parati. Bone Marrow Transplant. 2020;1-6. doi: 10.1038/s41409-020-0895-4 (ahead of print).

9. Bouffet E, Challinor J, Sullivan M, Biondi A, Rodriguez-Galindo C, Pritchard-Jones K. Early advice on managing children with cancer during the COVID-19 pandemic and a call for sharing experiences. Pediatr Blood Cancer. 2020;67:e28327.

10. COVID-19 and Childhood Cancer. Collaboration Space. Memphis; 2020. Available from: https://www.global.stjude.org/en-us/global-covid-19-observatory-and-resource-center-for-childhood-cancer/collaboration-space.html.

11. Coronavirus. Datos Abiertos. México; 2020. Available from: https://www. datos.gob. mx/busca/dataset/informacion-referente-a-casos-covid-19-en-mexicoat.

12. Gonzalez-Dambrauskas S, Vasquez-Hoyos P, Camporesi A, Diaz-Rubio F Pineres-Olave BE, Fernandez-Sarmiento J, et al. Pediatric critical care and COVID19. Pediatrics. 2020;2020:e20201766.

13. Liguoro I, Pilotto C, Bonanni M, Ferrari ME, Pusiol A, Nocerino A, et al SARS-COV-2 infection in children and newborns: a systematic review. Eur J Pediatr. 2020;2020:1-18.

14. Sun D, Li H, Lu XX, Xiao H, Ren J, Zhang FR, et al. Clinical features of severe pediatric patients with coronavirus disease 2019 in Wuhan: a single center's observational study. World J Pediatr. 2020;16:251-9.

15. Wu H, Zhu H, Yuan C, Yao C, Luo W, Shen X, et al. Clinical and immune features of hospitalized pediatric patients with coronavirus disease 2019 (COVID-19) in Wuhan, China. JAMA Netw Open. 2020;3:e2010895.
16. Chao JY, Derespina KR, Herold BC, Goldman DL, Aldrich M, Weingarten J et al. Clinical characteristics and outcomes of hospitalized and critically ill children and adolescents with coronavirus disease 2019 (COVID-19) at a tertiary care medical center in New York City. J Pediatr. 2020;223:14-19.

17. Sieni E, Pegoraro F, Casini T, Tondo A, Bortone B, Moriondo M, et al. Favourable outcome of coronavirus disease 2019 in a 1-year-old girl with acute myeloid leukaemia and severe treatment-induced immunosuppression. Br J Haematol. 2020;189:e222-4.

18. Lu X, Zhang L, Du H, Zhang J, Li YY, Qu J, et al. SARS-CoV-2 infection in children. N Engl J Med. 2020;382:1663-5.

19. Molica M, Mazzone C, Cordone I, Pasquale A, Niscola P, de Fabritiis P. SARS-CoV-2 infection anxieties and general population restrictions delay diagnosis and treatment of acute haematological malignancies. $\mathrm{Br} \mathrm{J}$ Haematol. 2020;190:e5-8.

20. Dai M, Liu D, Liu M, Zhou F, Li G, Chen Z, et al. Patients with cancer appear more vulnerable to SARS-CoV-2: a multicenter study during the COVID-19 outbreak. Cancer Discov. 2020;10:783-91.

21. Mehta V, Goel S, Kabarriti R, Cole D, Goldfinger M, Acuna-Villaorduna A, et al. Case fatality rate of cancer patients with COVID-19 in a New York hospital system. Cancer Discov. 2020;10:935-41.

22. Zhang J, Wang X, Jia X, Li J, Hu K, Chen G, et al. Risk factors for disease severity, unimprovement, and mortality in COVID-19 patients in Wuhan, China. Clin Microbiol Infect. 2020;26:767-72.

23. Yang C, Li C, Wang S, National Clinical Research Center for Child Health and Disorders and Children's Oncology Committee of Chinese Research Hospital Association. Clinical strategies for treating pediatric cancer during the outbreak of 2019 novel coronavirus infection. Pediatr Blood Cancer. 2020;67:e28248.

24. Terenziani M, Massimino M, Biassoni V, Casanova M, Chiaravalli S, Ferrari A, et al. SARS-CoV-2 disease and children under treatment for cancer. Pediatr Blood Cancer. 2020;2020:e28346.

25. Baruchel A, Bertrand Y, Boissel N, Brethon B, Ducassou S, Gandemer V, et al. COVID-19 and acute lymphoblastic leukemia of children and adolescents: first recommendations of the Leukemia Committee of the French Society for the Fight against Cancers and Leukemias in children and adolescents (SFCE). Bull Cancer. 2020;107:629-32.

26. Sullivan M, Bouffet E, Rodriguez-Galindo C, Luna-Fineman S, Khan MS, Kearns $P$, et al. The COVID-19 pandemic: a rapid global response for children with cancer from SIOP, COG, SIOP-E, SIOP-PODC, IPSO, PROS, CCl, and St Jude global. Pediatr Blood Cancer. 2020;67:e28409.

27. Shekerdemian LS, Mahmood NR, Wolfe KK, Riggs BJ, Ross CE, McKiernan $C A$, et al. Characteristics and outcomes of children with coronavirus disease 2019 (COVID-19) infection admitted to US and Canadian pediatric intensive care units. JAMA Pediatr. 2020. doi: 10.1001/jamapediatrics.2020.1948 (ahead of print).

28. Ruggiero A, Romano A, Attina G. Facing the COVID-19 outbreak in children with cancer. Drugs Context. 2020;9:1-3.

29. André N, Rouger-Gaudichon J, Brethon B, Phulpin A, Thebault E, Pertuisel S, et al. COVID-19 in pediatric oncology from French pediatric oncology and hematology centers: high risk of severe forms? Pediatr Blood Cancer. 2020;67:e28392.

30. Boulad F, Kamboj M, Bouvier N, Mauguen A, Kung AL. COVID-19 in children with cancer in New York City. JAMA Oncol. 2020;2020:e202028.

31. de Rojas T, Perez-Martinez A, Cela E, Baragano M, Galan V, Mata C et al. COVID-19 infection in children and adolescents with cancer in Madrid. Pediatr Blood Cancer. 2020;67:e28397.

32. Ferrari A, Zecca M, Rizzari C, Porta F, Provenzi M, Marinoni M, et al. Children with cancer in the time of COVID-19: an 8-week report from the six pediatric onco-hematology centers in Lombardia, Italy. Pediatr Blood Cancer. 2020;67:e28410.

33. Hrusak O, Kalina T, Wolf J, Balduzzi A, Provenzi M, Rizzari $C$, et al. Flash survey on severe acute respiratory syndrome coronavirus-2 infections in paediatric patients on anticancer treatment. Eur $\mathrm{J}$ Cancer. 2020;132:11-6.

34. Zachariah P, Johnson CL, Halabi KC, Ahn D, Sen Al, Fischer A, et al. Epidemiology, clinical features, and disease severity in patients with coronavirus disease 2019 (COVID-19) in a children's hospital in New York City, New York. JAMA Pediatr. 2020;2020:e202430.

35. Garazzino S, Montagnani C, Dona D, Meini A, Felici E, Vergine G, et al. Multicentre Italian study of SARS-CoV-2 infection in children and adolescents, preliminary data as at 10 April 2020. Eur Surveill. 2020;25:2000600.

36. Steliarova-Foucher E, Colombet M, Ries LA, Moreno F, Dolya A, Bray F et al. International incidence of childhood cancer, 2001-10: a population-based registry study. Lancet Oncol. 2017;18:719-31.

37. Keng MK, Sekeres MA. Febrile neutropenia in hematologic malignancies. Curr Hematol Malig Rep. 2013;8:370-8.

38. Lai CC, Wang CY, Wang YH, Hsueh SC, Ko WC, Hsueh PR. Global epidemiology of coronavirus disease 2019 (COVID-19): disease incidence, daily cumulative index, mortality, and their association with country healthcare resources and economic status. Int $\mathrm{J}$ Antimicrob Agents. 2020;55:105946 